\title{
Moral Rhetoric
}

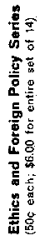

\section{ETHICS AND NATIONAL FUHPOSE}

Kenncth $W$. Thompson

Dr. Thompson exrlores the tersions that exist in the area of ethles and foragn policy today. Comments by Charles Donahuc. Stzpher G. Cary, Istael Klavin and Hicman Reissiz.

102. MOFALITY AND MODERIX WAR

John Couriney Murroy, S.J.
One of Americis outstsing Catholic theolopians examines the Chumch traditional leaching on was in the light of do. velopments in modern weapons.

103. RELIGION AND INTEMNATIONAL RESPONYIBILITY Robert Gordi

The religious and ethical heritage of the Judeo-Christian Tradition. Dr. Gordis araies is hoth practical ind relovant to our intersational respotisitilities today.

104. THE RECOVERY OF ETHICS

Paul $H$, Sitze:

An and ysis of decision-making at top government levels, this cssay olso eviluutes the contributicns of modem scientific thought to the recorsinuction of an ethical contert for politisal action.

L45. THE MORALITY AND POLITICS OF INTERYENTION Sarfred Halvern

Americun intervention in the affuirs of olher states is a grave and current mational coecerm. Dr. Halpem entunciates principles that are relevant to the surious discussion of any particular act of interventics, stuch as the Arablatoeli War and Vietnain.

106. THE LINITS $O Q$ NUCLEAR WAF

Thinking about the Do-able atel the Un-Do-able Pant Ramsey

in this essay the author of War and the Christian Constience In this essay the author of War and the Christian Constience a war ean be fought justly.

107. AN ALTERNATIVE TO WAR Gordon Zahn

Di. Zihn, one of the most persustive and periotent advocates of rim-violence. considers against the background of chrestened nuclear war a course of non-violent action.

108. HORAL TENSIONS IN INTERNATIONAL AFFAIRS John $G$. Benrete

After asserting the diffoctities involved in relating principles of marality to mary political derisiors and geticns, Dr. BenHett suggests ways in which these principles, properly en. ployed, fidp exploye some present moral/political dileminas

109. SOLTH AFRICA. PROBLEMS AND PROSFECTS Philip W. Quigg, with commentary by J. S. F. Bothe, Kenreth Carstens, vencu ilcka

The most potentially dangerous foreigr policy issuc for the U.S. is likely to be South Afnca. Against this belief, the managine editor of Foreinn Affetiss examines present problems and future prospects. His views are followed by those of people of diverse opinions.

110. FOREIGN AID: SORAL AND POLYTICAL ASPECTS Victor Forkiss

Foreiga aid policies have intennittently provoked nstional debates marked by acrimony, partisanship and confusion. Dr. Fetkiss here ofters standards on which foreim ald programs should be based and by which they can be judged.

11. IUST WAR AND VATICAN COUNCIL II: A CRITIOUE Robert W. Tucker, with commentary by George G. Higgins, Ralph Potter, Richard H. Cox, Paul Rarwe

The statements on war made by the Second Yatican Council derived from a tradition in. Which the concepis of just-war theory are pervasive. The relevance of theso statements, and the entire theory, is hese examined against the conditions of wodera warfare.
112. COUNTERINSURCENCY: SOKE PROBLEMS AND JHIFLICATIONS

Edgar S. Fumiss, Jr., with commentary by Chajles Burtori Marshall, William V. O'Arien

As the war in Vietram attests, the U.S. is in the process of working out means of warfase that are tappopriato to "wars of pationsil liberition." Dr. Funiss addresses himself here to sme of the problems posed by those means which are conprehended in the term "counterinsurgency."

113. THE UXIJED STATES IN ASIA:

\section{BVOLLTION AND CONTAINAENT}

David Mozingo

A pentrating analysis of both $\mathrm{C} . \mathrm{S}$, policy in Asia and Com. munist Chitra's response to it, this frank and disgassionate study by a RAND Corceration Senior Antalyst is basic to an understanding of what is happenirg today in Southeast Asia - and what is likely to bappen tamorrow.

114. MODERN WAR AND THE PURSUIT OF PEACE Theodore h Weber

Two opposed yet concurdert trends characterize modern warfare the development of complex auclcar weapons systenis and the einergence of invelued revolationary puertill techniques in licht of these trends and challenging interoretations of traditional just wiar thecy.

g01. THE MORAL DLLEMMA OF NUCLEAK WEAPONS: ESSAYS FKOM WORLDVIEW

Willam Clancy, ed

This, the first series of essays to be selected from worlduiew, brings together in a single discecssion political scientists, theologiuns, inilitar analysts and journifiots, No consensus was atternpted or attained the enly crommon criterion was the attempt to respond to the dilemma of muniear weapons in a way that is "morally responsible and politically wise," $\$ 1,00$

202. PEACE, THE CHURCHES AND THE BOM

Jomes Finn, ed.

Although the focus of discussion here is the preliminary statement on nuclear arms that was discussed in the third session of Vatican Cauncil II, the isstocs and problems arc

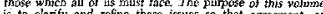
disagrement, will be as prccise as possible. agreement, or

203. NUCLEAR WEAPONS CAN THEIR SPREAD BE HALTED?

bettu Goet Loll

Nirs. Lall shows why the problem of limting the spread of nucleat weapons is one with shifing contours, but she also suggests seme measures that are presently feasihle and desirable.

204. THE U.S. AND WARS OF NATIONAL LIBERATION Quentir L. Quade

Dr. Quade, in a special repurt, recourts the major propositions, arguments and attitudes expressed during the courso of a GHIA semind in which authoritative spokesmen discussed wars of national liberation, e.g. Vietnem, in ralation to U.S, foreign policy.

205. U.S. POLICY IN THE FAR EAST

IDEOLOGY, RELIGION AND SUPERSTITION

Kenneth W: Thempon, Hame J. Morgenthes, Jorald C. Bfower In an atternot to separate the idolatrous and the ephemeral from the valio objects of national dedication, three members of the CRIA Board of Trustecs discuss U.S. policy in the Far East in relation to its history and probable future as well as to the presert involvement in Vietram. \$1,75 

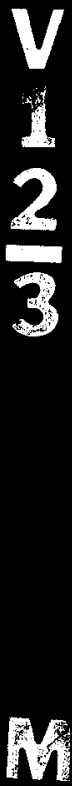

8

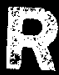

6

9) 